\section{TICKBORNE DISEASES}

\section{Detection of Anaplasma phagocytophilum in Dermacentor reticulatus ticks}

IN Europe, cases of Lyme borreliosis, tickborne encephalitis and granulocytic anaplasmosis have increased in human beings, domestic animals and wildlife, expanding their geographical ranges to much of Scandinavia and eastern Europe.
Proposed explanations include improved surveillance and diagnosis, changes in human behaviour, climate change, and increasing numbers of reservoir hosts and vectors (Heyman and others 2010). With respect to reservoirs of Anaplasma phagocytophilum, the causative agent of granulocytic anaplasmosis, the red deer (Cervus elaphus) is included in the list of European reservoirs, with roe deer (Capreolus capreolus), bank voles (Myodes species) and wood mice (Apodemus species). This letter describes a new possible vector species.

The disease monitoring activities of our WILDSCREEN network (Linden and others 2011) include collection of ticks from wild species and testing them for infectious agents. In the autumn of 2010, as well as the usual Ixodes ricinus ticks, we unexpectedly found 35 ticks morphologically compatible with Dermacentor reticulatus on an adult male red deer. The species was confirmed by sequencing the amplicon retrieved from a PCR targeting the Dermacentor-specific ITS2 genomic segment (Dobec and others 2009), thus confirming recent findings showing that $D$ reticulatus occurs at far more sites than were previously known in northern Europe (Dautel and others 2006). Moreover, a PCR targeting the A phagocytophilumspecific major surface protein-2 (MSP2)encoding gene (Massung and Slater 2003) yielded five positive $D$ reticulatus ticks; the DNA sequence of the PCR showed 96.8 per cent homology with the reference sequence.

Vectors of A phagocytophilum have always been considered to be ticks in the I ricinus subgroup of hard ticks, including the sheep tick (I ricinus) in Europe, the taiga tick (Ixodes persulcatus) in Asia, the deer tick (Ixodes scapularis) in eastern North America and the western black-legged tick (Ixodes pacificus) in western North America (Brown and others
2005). According to our results, $D$ reticulatus ticks in general, or at least some $D$ reticulatus isolates, should now be included in the list of putative vectors. It remains to be seen whether the presence of A phagocytophilum DNA results in effective transmission capacity by $D$ reticulatus, and whether A phagocytophilum variants isolated from $D$ reticulatus display a pathotype similar to that of variants transmitted by I ricinus ticks.

M. Wirtgen, A. Nahayo, A. Linden, Network of Wildlife Diseases, Department of Infectious and Parasitic Diseases, M. Garigliany, D. Desmecht, Department of Pathology,

Faculty of Veterinary Medicine, University of Liège, B43a, Boulevard de Colonster 20, 4000 Liège, Belgium

\section{References}

BROWN, R. N., LANE, R. \& DENNIS, D. T. (2005) Geographic distributions of tick-borne diseases and their vectors. In Tick-Borne Diseases of Humans. Eds J. L. Goodman, D. T. Dennis, D. E. Sonenshine. American Society for Microbiology Press. pp 363-391 DAUTEL, H., DIPPEL, C., OEHME, R., HARTELT, K. \& SCHETTLER, E. (2006) Evidence for an increased geographical distribution of Dermacentor reticulatus in Germany and detection of Rickettsia sp RpA4. International Journal of Medical Microbiology 296 (Suppl 40), $149-156$

DOBEC, M., GOLUBIC, D, PUNDA-POLIC, V., KAEPPELI, F. \& SIEVERS, M. (2009) Rickettsia helvetica in Dermacentor reticulatus ticks. Emerging Infectious Diseases 15, 98-100

HEYMAN, P., COCHEZ, C., HOFHUIS, A., VAN DER GIESSEN, J., SPRONG, H., PORTER, S. R., LOSSON, B., SAEGERMAN, C., DONOSOMANTKE, O., NIEDRIG, M. \& PAPA, A. (2010) A clear and present danger: tick-borne diseases in Europe. Expert Review of Anti-Infective Therapy 8, 33-50

LINDEN, A., WIRTGEN, M. VOLPE, S., NAHAYO, A., PIRSON, J., PATERNOSTRE, J. \& GREGOIRE, F (2011) Surveillance of wildlife diseases in Belgium. Epidémiologie et Santé Animale (In press)

MASSUNG, R. F. \& SLATER, K. G. (2003) Comparison of PCR assays for detection of the agent of human granulocytic ehrlichiosis, Anaplasma phagocytophilum. Journal of Clinical Microbiology 41, 717-722

doi: 10.1136/vr.d1053 


\section{Detection of Anaplasma phagocytophilum in
Deterinary
Dermacentor reticulatus ticks}

M. Wirtgen, A. Nahayo, A. Linden, et al.

Veterinary Record 2011 168: 195

doi: 10.1136/vr.d1053

Updated information and services can be found at:

http://veterinaryrecord.bmj.com/content/168/7/195.full.html

\section{These include:}

References This article cites 4 articles, 1 of which can be accessed free at: http://veterinaryrecord.bmj.com/content/168/7/195.full.html\#ref-list-1

Email alerting Receive free email alerts when new articles cite this article. Sign up in service the box at the top right corner of the online article.

Notes

To request permissions go to:

http://group.bmj.com/group/rights-licensing/permissions

To order reprints go to:

http://journals.bmj.com/cgi/reprintform

To subscribe to BMJ go to:

http://group.bmj.com/subscribe/ 